\title{
Relationship between psychological well-being Mudflow resident \\ gratitude around Lapindo
}

\author{
Dian Anggraini ${ }^{*}$ and Listyati Palupi ${ }^{1}$
}

${ }^{1}$ Personality and Social Psychology Department, Faculty of Psychology, Airlangga University, Surabaya, Indonesia

\begin{abstract}
The Lapindo Mud is a natural disaster occurred 13 years ago and still erupts today. Of course this disaster affects the people who live around it. The people who are the victims of the mud disaster is still survive. Therefore, it is important to understand how this people could survive in this disaster situation. Thus, the purpose of this quantitative, correlational study is to investigate the relationship between gratitude and psychological well-being for the resident around Lapindo mudflow. This research used quantitative method with survey. The scale used was The Gratitude Questionnaire-Six Item Form (GQ-6) developed by McCullough to measured the level of gratitude and Javanese Psychological Well-being Scale developed by Palupi to measured psychological well-being. The result showed that there is relationship between gratitude and psychological well-being in the population/resident around Lapindo mudflow.
\end{abstract}

\section{Introduction}

May 29, 2006, was a historical moment for Sidoarjo, East Java. On that day, blazing hot $100^{\circ} \mathrm{C}$ of gas and mud erupted from the ground. That phenomenon, or rather, natural disaster, later known as "Lumpur Lapindo" or Lapindo mudflow. Lapindo mudflow flooded some nearby villages in three different districts of Sidoarjo [1-4]. The villages which were flooded are located in three different districts named, Tanggulangin, Porong, and Jabon. The villages that got flooded were Renokenongo Siring (east side), Jatirejo (east side), Glagaharum (west side), Kedungbendo Ketapang (east side), and Besuki (west side) [4]. The area growth of those three districts categorized as very dynamic and have a highly populated citizens because of the industrial region, settlements, and the main access to the bigger cities in south and east side of Sidoarjo [5]. Apart from those villages, "Lumpur Lapindo" also flooded nearby factories, lands, and Surabaya-Gempol highway [6].

The happening of Lapindo mudflow has caused some issues to arise. The point of eruption of the mud was located on highly populated settlement. This causes tens of thousands of citizens to bear the socio-economic burden [1]. The east side of Lapindo mudflow is a shrimp aquaculture area. Mud that came out caused pollution in the area so

\footnotetext{
* Corresponding author: listyati.palupi@psikologi.unair.ac.id
} 
according to calculations from the province, farmers suffered losses of more than Rp. 13 billion [7]. Because the overflow area also inundated the industrial area, which is a source of work for residents and residents outside the city, it is estimated that the total loss until August 2007 reached Rp. 28.3 billion for infrastructure assets, the industrial sector and its indirect impact on the economy of East Java Province [6]. In addition, in the western part of the Lapindo mudflow is the main route connecting major cities in the south and east to cities in the north, such as Surabaya as a trading center in East Java.

Psychological well-being (PWB) is conditions where an individual has a purpose in life to be more meaningful, realize the potential possessed, creating and managing the quality of their relationships with others, responsible for his life and trying to develop and explore himself [8]. Various socio-economic losses that are both experienced directly by the resident and the local government certainly have an impact on the psychological welfare of disaster victims, namely residents around Lapindo mudflow. Residents experience loss of their homes and sources of work, which are basic human needs. That resulted in the difficulty to fulfill other basic needs. This is in line with Veenhoven's statement which explains the role of economic factors on happiness in general. His research on rich and poor countries found that economic factors affect individual welfare [9]. In addition, according to Ryff, one of the factors affecting PWB is socioeconomic status [10]. The Lapindo mudflow disaster caused the resident changes in socioeconomic status, which means the population also experienced a change in psychological well-being.

According to Diener, psychological well-being is important because high psychological well-being will support better health, prolong life, increase life expectancy and describe the quality of life and functioning of individuals [11]. But the psychological well-being of the population around Lapindo mud must have changed due to the unexpected disaster before. On the other hand, Wood, Joseph and Maltby's research shows gratitude has a positive relationship with several aspects of PWB, namely personal growth, positive relationships with others, life goals and self-acceptance [12]. According to Emmons and Stern, gratitude is a feeling that occurs when someone acknowledges that he received valuable benefits from another. The main purpose of gratitude is to reflect back the good received [13]. Haworth (1997) also states that individual welfare can be improved through the expression of gratitude. Other research conducted by Putri [15] also showed a significant positive relationship between gratitude and PWB in college students. Therefore, this study aims to see whether Gratitude also correlate with PWB in the population of residents around the Lapindo mudflow.

\section{Method}

This research using quantitative method with associated descriptive approaches. it is located in Kupang village, Jabon and Kebonagung village, Sukodono - Sidoarjo. Kupang is the one of the villages that their rivers polluted by Lapindo mudflow. Meanwhile, Kebonagung is the one of the civil shelter. The subject of this research is the civil of the polluted area of Lapindo mudflow.

The instrument used by researchers consisted of questionnaires. The data collection technique in this study is a survey technique, while the subject taking technique uses Accidental Sampling. Gratitude is measured using The Gratitude Questionnaire-Six Item Form (GQ-6) developed by McCullough and PWB is measured by Javanese Psychological Well-being Scale developed by Palupi. The analysis technique uses the correlation technique or Spearman's Rho, a nonparametric statistical technique with the help of BMI SPSS Statistics version 20. 


\section{Data and Results}

Table 1. Descriptive Characteristics.

\begin{tabular}{|c|c|}
\hline Characteristics & Frekuensi \\
\hline $\begin{array}{l}\text { Jenis kelamin } \\
\text { Wanita } \\
\text { Laki-laki }\end{array}$ & $\begin{array}{l}55 \% \\
45 \%\end{array}$ \\
\hline $\begin{array}{l}\text { Usia } \\
\qquad \begin{array}{l}\text { Range } \\
\text { Mean } \pm \mathrm{SD}\end{array}\end{array}$ & $\begin{array}{l}17-58 \\
30.41 \%\end{array}$ \\
\hline $\begin{array}{l}\text { Pendidikan } \\
\text { SD } \\
\text { SLTP/SMP } \\
\text { SLTA/SMA } \\
\text { Sarjana/S1 }\end{array}$ & $\begin{array}{l}10 \% \\
45 \% \\
36.3 \% \\
8.8 \%\end{array}$ \\
\hline $\begin{array}{l}\text { Penghasilan } \\
\quad<\text { RP.1.000.000 } \\
\text { RP.1.000.000-RP.5.000.000 } \\
\text { RP.5.000.000-RP. } 10.000 .000 \\
\quad>\text { RP. } 10.000 .000\end{array}$ & $\begin{array}{l}47.5 \% \\
50 \% \\
1.3 \% \\
1.3 \%\end{array}$ \\
\hline $\begin{array}{l}\text { Desa } \\
\text { Desa Kupang } \\
\text { Desa Kebonagung }\end{array}$ & $\begin{array}{l}62.5 \% \\
37.5 \%\end{array}$ \\
\hline
\end{tabular}

Based on the results of data collection, total subjects obtained were 80 people consisting of $55 \%$ women, as many as 44 people and $45 \%$ men, as many as 36 people. The ages of the subjects varied, with ages ranging from 17 years to 58 years. Based on education, subjects were divided into 4 categories, namely elementary school level of 8 people or $10 \%$, junior high school with 36 people or $45 \%$, high school as many as 29 people or $36.3 \%$ and S1 as many as 7 people or $8.8 \%$. The income of the subjects also varied and was classified into 4 categories, less than Rp.1.000.000 as many as 38 people or $47.5 \%$, between Rp. 1.000 .000 to Rp.5.000.000 by 40 or $50 \%$, between Rp.5.000.000 to Rp. 10.000 .000 by 1 person or $1.3 \%$ and above Rp. 10.000 .000 by 1 person or $1.3 \%$. Data was taken from 2 villages, namely Kupang and Kebonagung. From Kupang, researchers got 50 subjects or $62.5 \%$, while from Kebonagung researchers got 30 subjects or $37.5 \%$.

Table 2. Descriptive Variables based on score.

\begin{tabular}{|lll|}
\hline & Psychological Well-being & Gratitude \\
\hline Total & 80 & 80 \\
Range & $6-17$ & $22-36$ \\
Mean \pm SD & $13.16 \pm 3.29$ & $30.16 \pm 4.47$ \\
\hline
\end{tabular}


In measuring PWB variables it can be seen that the range is at $6-17$, which means the lowest value is 6 and the highest value is 17. The average value of the variable is 13.16. In the gratitude variable it can be seen that the range is $22-36$, which means the lowest value is 22 and the highest value is 36 . The average value of the variable is 30.16 . This result can be used to normalize the measurement results.

Table 3. Descriptive Variables based on norms.

\begin{tabular}{|llcll|}
\hline & \multicolumn{2}{l}{ Psychological Well-being } & \multicolumn{2}{l|}{ Gratitude } \\
\hline High & 4 & $5 \%$ & 20 & $25 \%$ \\
Normal & 58 & $72.5 \%$ & 46 & $57.5 \%$ \\
Low & 18 & $22.5 \%$ & 14 & $17.5 \%$ \\
\hline
\end{tabular}

The data obtained can be categorized into 3 categories based on the values obtained in each data, namely high, medium and low. Data is classified as high if the value is greater than mean $+\mathrm{SD}$, is classified as moderate if the value is between mean-SD and mean $+\mathrm{SD}$, and is classified as low if the value is less than mean-SD.

From pwb variables 4 data or 5\% are classified as high, 58 data or $72.5 \%$ are classified as moderate and 18 data or $22.5 \%$ are classified as low. From the gratitude variable as many as 20 data or $25 \%$ are classified as high, 46 data or $57.5 \%$ are classified as moderate and 14 data or $17.5 \%$ are classified as low.

Table 4. Assumption Normality.

\begin{tabular}{|c|c|c|}
\hline & Psychological Well-being & Gratitude \\
\hline $\begin{array}{l}\text { Kolmogorov- } \\
\text { Smirnov Z }\end{array}$ & 2.238 & 1.203 \\
\hline $\begin{array}{l}\text { Asymp. Sig. (2- } \\
\text { tailed) }\end{array}$ & 0.000 & 0.111 \\
\hline
\end{tabular}

From the normality assumption test with Kolmogorov-Smirnov it is known that the results of the PWB variable probability test are 0,000 and the free variable is 0.111 . This means that the data distribution is not normal, so the correlation test used is Spearman's Rho because the assumption of normality is not fulfilled, which is greater than 0.05 .

Table 5. Correlation Test Result.

\begin{tabular}{|ll|l|}
\hline & \multicolumn{1}{|c|}{ Gratitude } \\
\hline $\begin{array}{l}\text { Psychological Well- } \\
\text { being }\end{array}$ & $\begin{array}{l}\text { Correlation } \\
\text { Coefficient }\end{array}$ & 0.421 \\
& Sig. (2-tailed) & 0.000 \\
& $\mathrm{~N}$ & 80 \\
\hline
\end{tabular}

In the table above shows the complete amount of data that is 80 data and no missing data. It can be seen that the significance value is two variables of 0.000 , where the significant value is less than 0.05 which can be interpreted that there is a significant relationship between the two research variables. In other words there is a significant relationship between gratitude and pwb in the subjects studied. 
The results of the correlation coefficient show 0.421 where the number is positive and indicates the nature of the relationship is moderate. So it can be concluded that there is a moderate relationship.

Table 6. Correlation Test Result based on Villages.

\begin{tabular}{|ll|l|l|}
\hline & \multicolumn{1}{|c|}{$\begin{array}{c}\text { KupangVillage } \\
\text { Gratitude }\end{array}$} & \multicolumn{1}{|c|}{$\begin{array}{c}\text { Kebonagung } \\
\text { Village } \\
\text { Gratitude }\end{array}$} \\
\hline & Correlation Coefficient & 0.593 & 0.711 \\
Psychological & Sig. (2-tailed) & 0.000 & 0.000 \\
Well-being & $\mathrm{N}$ & 50 & 30 \\
\hline
\end{tabular}

The table above shows the strength between pwb and gratitude relationships in each village. In the village of Kupang the relationship strength was 0.593 or $59.3 \%$. While in Kebonagung village the displacement force was 0.711 or $71.1 \%$. It can be concluded that the relationship between gratitude and pwb in kebonagung village is stronger than that in kupang village.

\section{Discussion}

This study is in accordance with previous research which shows that gratitude is important for psychological well-being in relation to personality [14]. In accordance with research conducted by Putri [15] where the research shows that there is a significant positive relationship between gratitude and PWB in college students. From the results of these studies can be interpreted even with different research participants but still shows a significant positive relationship between gratitude and PWB.

According to Watkins, gratitude is the most important power to achieve a better life so that it has a purpose and purpose in life that is inseparable from the existence of gratitude for the life that is being lived. Grateful individuals will receive every contribution made by someone else [14]. During the data collection process, researchers interact directly with participants. From that interaction, participants said that at first they were disappointed and did not know how to deal with the disaster, but now, after more than 10 years of this disaster, they are more able to accept and do what they can to support their families. Some participants also said they were grateful for the life and health they still feel today. Some conditions found can indicate that participants have a good PWB because according to Ryff the characteristics of people who have high psychological well-being are independent, have the ability to adapt to the surrounding environment, the desire to continue to grow and develop in all respects, a warm relationship with others, have certain goals to be achieved in life, and a positive assessment of themselves [8]. Gratitude, according to the participants, also made them more calm in their lives even though they lived in an area close to the location of the Lapindo mudflow. This is in line with research conducted by Wood, Joseph and Maltby [14] which says that gratitude is one of the positive power that most benefits individuals and that gratitude is one thing that can affect PWB

In the research results also found there are differences in the strength of the relationship between Gratitude and PWB between Kupang and Kebonagung villages. Kebonagung Village has a stronger relationship than Kupang Village. Kupang village is very close to Lapindo mud because the river that passes through their village is also passed by a residue from Lapindo mud. While the Kebonagung Village is located quite far away and does not come into direct contact with mud like the Kupang village. The similarity that they 
experienced in relation to the Lapindo mudflow disaster was that they smelled a rather pungent odor from the Lapindo mud when carried by the wind or during the rainy season. It can be concluded that the difference in location is what causes differences in the strength of the relationship between gratitude and PWB between the villages of Kupang and Kebunagung.

\section{References}

1. A. Mazzini, et al, Science Direct 375-388 (2007)

2. R. J. Davies, et al, ScienceDirect 627-628 (2008)

3. H. Z. Abidin, et al, Springer 595-603 (2009)

4. B. Batubara, Kronik Lumpur Lapindo (InsistPress, Yogyakarta, 2012)

5. F. Nuraini, Swara Bhumi e-Journal Pendidikan Geografi FIS Unesa 2 No. 2, 48-58 (2015)

6. H. McMichael, Buletin of Indonesian Economic Studies, 45 No. 1, 73-83 (2009)

7. A. R. Fitrianto, Science Direct, 168-176 (2012)

8. C. D. Ryff, Exploration on The Meaning of Psychological Well-Being Journal of Personality and Social Psychological, 57, 1060-1081(1989)

9. M. Argyle, The Psychology of Happiness, 2nd ed, (Routledge, New York, 2001)

10. C. D. Ryff, Current Directions in Psychological Science, 4, 99-104 (1995)

11. T. M. Harimukthi, S. K. Dewi, Jurnal Psikologi Undip, 13(1), 64-77 (2014)

12. A. M. Wood, J. J. Froh \& A. W. Geragthy, Clinical Psychology Review 890-905 (2010)

13. A. R. Emmons \& R. Stern, Journal of Clinical Psychology: In Session, 69, 846-855 (2013)

14. A. M. Wood, S. Joseph \& J. Maltby, Personality and Individual Differences, 46, 443447 (2009)

15. F. O. Putri, Hubungan antara Gratitude dan Psychological Well-Being pada Mahasiswa, Thesis, Universitas Indonesia (2012) 